\title{
Coexistent sickle-cell anemia and autoimmune disease in eight children: pitfalls and challenges
}

\author{
Valerie Li-Thiao-Te ${ }^{1 *} \mathbb{D}$, Florence Uettwiller ${ }^{2}$, Pierre Quartier ${ }^{2,3,4}$, Florence Lacaille ${ }^{5}$, Brigitte Bader-Meunier ${ }^{2,3,4}$,
} Valentine Brousse ${ }^{6}$ and Mariane de Montalembert ${ }^{6}$

\begin{abstract}
Background: Patients with sickle cell disease (SCD) present a defective activation of the alternate complement pathway that increases the risk of infection and is thought to predispose to autoimmune disease (AID). However, coexisting AID and SCD is rarely reported, suggesting possible underdiagnosis due to an overlapping of the symptoms.

Study design: Among 603 patients with SCD followed between 1999 and June 2016, we retrospectively searched for patients with coexisting SCD and AID.

Results: We identified 8 patients aged from 7 to 17 years diagnosed with AID; juvenile idiopathic arthritis $(n=3)$, systemic lupus erythematosus $(n=2)$, Sjögren's syndrome $(n=1)$ and autoimmune hepatitis $(n=2)$. The diagnosis of AID was often delayed due to similarities of the symptoms with those of SCD. Patients treated with steroids experienced multiple vasoocclusive crises and received prophylactic chronic blood transfusions when it was possible. Tolerance to other immunosuppressive and biological treatments, such as anti-TNF agents, was good. A remission of AID was achieved in 4 patients, without worsening the course of the SCD. One patient underwent a geno-identical hematopoietic stem cell transplantation that cured both diseases. Another one underwent a successful liver transplantation.
\end{abstract}

Conclusion: Coexistence of AID and SCD generates diagnostic and therapeutic challenges. Early diagnosis of AID is important to define the best treatment, which may include targeted biological therapy.

Keywords: Sickle cell disease, Autoimmune disease, Juvenile idiopathic arthritis, Systemic lupus erythematosus, Children, Biological therapy

\section{Background}

Sickle cell disease (SCD) is a common inherited condition in African, Caribbean, and Mediterranean countries. Production of abnormal hemoglobin $\mathrm{S}$ is responsible for the sickling of red blood cells in deoxygenated conditions. SCD manifests itself as chronic intravascular hemolysis, vaso-occlusion and painful crises. Over time, multiple organ damage can develop. Patients with SCD display a defective activation of the alternate complement pathway, leading to an increased risk of infection with encapsulated bacteria (pneumococci, Haemophilus influenzae) [1-3]. It was suggested that complement abnormalities could predispose to autoimmune disease (AID) [4]. However, the frequency of coexisting SCD and AID has not been evaluated, and most data come from case reports [5-14]. Manifestations of AID, such as fever, polyarthritis, and multiorgan involvement, can also be caused by SCD, leading to a delay in diagnosing the AID [11]. Furthermore, antiinflammatory drugs such as steroids and immunosuppressive therapy used to treat AID can induce severe SCD complications.

\section{Study design}

Between 1999 and June 2016, 603 patients with SCD aged under 18 years were seen at the hemoglobinopathy reference center of the Necker Hospital, Paris, France.

1Onco-Hématologie Pédiatrique, Centre Hospitalier Universitaire Amiens,

Amiens, France

Full list of author information is available at the end of the article 
Among them, we searched for patients with coexisting SCD and AID.

We retrospectively collected data from the medical records of SCD patients followed in our institution, the largest Pediatric University-Hospital in France, which has a national reference center for SCD and a national reference center for pediatric rheumatology diseases. Started in 2007, data from the patients referred to the pediatric rheumatology team were registered in the CEMARA database, a nationwide web-based information for rare diseases [15] approved by the French patients Data Protection Authority (Commission Nationale de l'Informatique et Libertés, CNIL), after patients'/parents' information and verification of their non-opposition. In accordance with the French legislation, no ethics committee agreement was requested for such a retrospective survey.

\section{Results}

Among the 603 children with SCD followed between 1999 and June 2016, we identified 8 patients aged from 7 to 17 years, who developed an AID. All patients were Afro-Caribbean homozygous SCD ( $\mathrm{Hb}$ SS) children either diagnosed by neonatal screening (patient 1, 6, 7 and \#8) or during infancy (patient 2, 3, 4 and \#5). The diagnoses were juvenile idiopathic arthritis (JIA, $n=3$ ), systemic lupus erythematosus (SLE, $n=2$ ), Sjögren's syndrome $(n=1)$ and autoimmune hepatitis $(\mathrm{n}=2)$. These 8 patients received joint follow-up by hematologists, rheumatologists and an hepatologist. Table 1 reports the medical history before the diagnosis of the AID and the clinical and laboratory findings that led to the diagnosis of AID.

In one patient, SLE was diagnosed within a few weeks of the onset of the symptoms because of fingers swelling, not a common site of vaso-occlusion in adolescents with SCD. In another patient, alopecia and aphthous stomatitis helped diagnose the SLE several months after the first neurologic symptoms and polyarthritis had appeared. In some patients, the diagnosis was delayed for several years (Table 1). Before the diagnosis of JIA, patients \#2 and \#4 had had a long history of joint pain and ankle and knee swelling, first ascribed to SCD and treated as SCD complications (analgesics, hyperhydratation, hydroxyurea for patient \#2 and exchange transfusion for patient \#4). Patients 5 and \#8 displayed biological signs of liver dysfunction (elevation of AST and ALT, cholestasis). Liver biopsy showed lymphoplasmocytic infiltrates and mild fibrosis compatible with autoimmune hepatitis. For patient \#7 diagnosed with SLE, cerebral MRI was performed in response to the worsening of neurologic symptoms and showed periventricular hyperintensity and cortico-subcortical atrophy compatible with lupus lesions. The tolerance to AID treatment was good. Among the 4 patients treated with steroids, 3 had a concomitant exchange transfusion program in order to prevent vaso-occlusive crises and 1 received hydroxyurea. Red blood cell alloimmunisation in 1 patient required a switch from transfusion to hydroxyurea. Complete remission of the AID was obtained for 4 patients with a classical immunosuppressive treatment $(n=1)$, biological treatment $(n=2)$ or genoidentical hematopoietic stem cell transplantation $(\mathrm{n}=1)$, although 1 patient (patient \#4) had arthritis sequelae. Despite being associated with AID, the SCD course was stable for 5 patients. The patient who underwent stem cell transplantation was cured of both AID and SCD. Patient \#4 who did not receive hydroxyurea or transfusion experienced several vaso-occlusive crises during the follow up. Patient \#8 who underwent liver transplantation due to chronic infectious cholangitis, presented multiple post-transplant complications (rejection, biliary stenosis, high blood pressure, posterior reversible encephalopathy), but had a normal liver function and a much improved quality of life at the last follow up. Table 2 reports the treatments and last follow-up data.

\section{Discussion}

We report 8 cases of coexisting SCD and AID including polyarticular JIA and juvenile SLE in a cohort of 603 patients with SCD. The incidence of AID in France in an ethnic matched population is not known, as it is not allowed to compare diseases according to patients' ethnicity. These cases highlight the diagnostic difficulties raised by the symptom overlapping between AID and SCD (e.g., polyarthritis, anemia, and fever) and the therapeutic challenges. Nevertheless, the use of immunosuppressive drugs (except steroids), including new drugs such as TNF $\alpha$ antagonist was well tolerated and provided durable AID remissions, without worsening the course of the SCD when associated to specific SCD treatments.

AID such as SLE [16] and polyarticular JIA [17, 18] are more common in Blacks than in other ethnic groups. In addition to genetics, patients with SCD present functional asplenia and defective activation of the alternate complement pathway [1-4]. Although published data focused on functional complement abnormalities, it would be interesting to assess the impact of functional asplenia itself in the occurrence of AID [19]. However, the coexistence of AID and SCD seems to be rare, potentially underdiagnosed, and its prevalence is unknown. In a study of 30 patients with SCD and connective tissue disease, 15 patients $(50 \%)$ had rheumatoid arthritis, 13 (44\%) had SLE, 1 (3\%) had Sjögren's syndrome, and 1 (3\%) had sclerodermia [20]. Most data on coexistent AID and SCD come from anecdotal case-reports [5-14] describing patients SLE $[2,8-11]$, or far less often, JIA [5-7] or autoimmune hepatitis [12-14].

Our patients reflect the diagnostic challenges of JIA in children with SCD. We report diagnostic delays from 1 to 8 years, as could be found in previous reports [5-7]. 
Table 1 Medical history, clinical and biological findings at presentation in our patients

\begin{tabular}{|c|c|c|c|c|c|c|c|c|}
\hline Patient & 1 & 2 & 3 & 4 & 5 & 6 & 7 & 8 \\
\hline$\overline{\text { Sex }}$ & $M$ & $M$ & $F$ & $M$ & $M$ & $\mathrm{~F}$ & $\mathrm{~F}$ & $\mathrm{~F}$ \\
\hline $\begin{array}{l}\text { Medical history } \\
\text { related to SCD }\end{array}$ & $\begin{array}{l}\text { ACS ( } 3 \text { episodes) } \\
\text { Recurrent VOC }\end{array}$ & $\begin{array}{l}\text { Recurrent } \\
\text { polyarthralgia }^{\mathrm{a}}\end{array}$ & Recurrent VOC & $\begin{array}{l}\text { Recurrent VOC } \\
\text { Osteomyelitis } \\
\text { right femur } \\
\text { Chronic hepatitis B }\end{array}$ & $\begin{array}{l}\text { Recurrent VOC } \\
\text { Acute cholecystitis, } \\
\text { Salmonella } \\
\text { septicemia } \\
\text { Bilateral } \\
\text { avascular } \\
\text { necrosis of } \\
\text { femoral heads }\end{array}$ & Recurrent VOC & $\begin{array}{l}\text { Recurrent VOC } \\
\text { ACS ( } 3 \text { episodes) }\end{array}$ & $\begin{array}{l}\text { Recurrent VOC } \\
\text { ACS } \\
\text { Acute splenic } \\
\text { sequestration } \\
\text { Recurrent } \\
\text { cholangitis }\end{array}$ \\
\hline Type of AID & SLE & $J \mid A$ & $J \mid A$ & $J \mid A$ & AlH & Sjogrën'syndrome & SLE & AlH \\
\hline $\begin{array}{l}\text { Age at onset of } \\
\text { AID (years) }\end{array}$ & 13 & 4 & 7 & 4 & 17 & 11 & 15 & 3 \\
\hline $\begin{array}{l}\text { Age at } \\
\text { diagnosis of } \\
\text { AID (years) }\end{array}$ & 13 & 13 & 7 & 6 & 17 & $\begin{array}{l}13 \text { (11 for initial } \\
\text { diagnosis of JIA) }\end{array}$ & 15 & 3 \\
\hline Symptoms & $\begin{array}{l}\text { Asthenia, } \\
\text { denutrition } \\
\text { polyarthritis } \\
\text { fingers and toes } \\
\text { hepatomegaly } \\
\text { pericarditis }\end{array}$ & $\begin{array}{l}\text { Polyarthritis } \\
\text { left knee and } \\
\text { right ankle } \\
\text { severe } \\
\text { arthropathy } \\
\text { at } 10 \text { y } \\
\text { uveitis }\end{array}$ & $\begin{array}{l}\text { Polyarthritis } \\
\text { (temporo- } \\
\text { mandibular } \\
\text { arthritis and } \\
\text { sacroiliitis) }\end{array}$ & $\begin{array}{l}\text { Polyarthralgia } \\
\text { bilateral knee } \\
\text { arthritis } \\
\text { Asthenia, } \\
\text { weight loss }\end{array}$ & Polyarthralgia & $\begin{array}{l}\text { Polyarthralgia } \\
\text { (spine); knee } \\
\text { arthritis; } \\
\text { Secondary } \\
\text { recurrent } \\
\text { parotiditis; } \\
\text { xerostomia } \\
\text { at } 13 \text { y }\end{array}$ & $\begin{array}{l}\text { Polyarthritis; } \\
\text { pleuritis, } \\
\text { pericarditis, } \\
\text { aphthous } \\
\text { stomatitis, } \\
\text { alopecia; } \\
\text { pulmonary } \\
\text { hypertension; } \\
\text { behavior disorder }\end{array}$ & $\begin{array}{l}\text { Hepatomegaly; } \\
\text { jaundice }\end{array}$ \\
\hline ESR $(\mathrm{mm} / \mathrm{h})$ & 74 & 95 & 34 & 86 & 67 & 14 & 84 & 88 \\
\hline $\operatorname{lgG}(g / \operatorname{l)}$ & 38 & 26 & - & - & 35 & 23 & 30 & 26 \\
\hline ANA pattern & $\begin{array}{l}1 / 1280 \\
\text { homogeneous }\end{array}$ & $\begin{array}{l}1 / 160 \\
\text { speckled }\end{array}$ & Negative & $\begin{array}{c}1 / 80 \\
\text { homogeneous }\end{array}$ & $1 / 80$ & $1 / 1280$ & $\begin{array}{c}1 / 80 \\
\text { speckled }\end{array}$ & $1 / 160$ \\
\hline $\begin{array}{l}\text { Others } \\
\text { immunological } \\
\text { features }\end{array}$ & $\begin{array}{l}\text { Anti-DNA } \\
\text { antibodies + } \\
(43 \mathrm{UI} / \mathrm{ml}) \\
\text { Coombs + }\end{array}$ & RF negative & RF positive & & $\begin{array}{l}\text { Anti-U1RNP + } \\
\text { Farr test 29\% }\end{array}$ & $\begin{array}{l}\text { Anti-SSA, SSB + } \\
\text { Anti-U1RNP + } \\
\text { Antiß2GP1 + } \\
\text { Antiphospholipid } \\
\text { antibodies + }\end{array}$ & $\begin{array}{l}\text { Anti-DNA } \\
\text { antibodies + } \\
(44 \cup / 1) \\
\text { pANCA } \\
\text { Coombs + } \\
\text { Antiplatelets } \\
\text { antibodies + } \\
\text { AntiB2GP1 + } \\
\text { anticardiolipin + } \\
\text { Neutropenia }\end{array}$ & $\begin{array}{l}\text { C-ANCA + } \\
\text { Smooth } \\
\text { muscle } \\
\text { antibodies + } \\
(1 / 50)\end{array}$ \\
\hline
\end{tabular}

VOC vaso-occlusive crises, $A C S$ acute chest syndrome, $A I D$ autoimmune disease, SLE systemic lupus erythematosus, JIA juvenile idiopathic arthritis, $A I H$ autoimmune hepatitis, $M$ male, $F$ female, ESR erythrocyte sedimentation rate, $A N A$ antinuclear antibodies, $R F$ rheumatoid factor

afirst ascribed to SCD but probably related to JIA

Features arguing against SCD as the cause included bilateral symmetric pain limited to the joints, failure of hydroxyurea, persistent high erythrocyte sedimentation rate. In most previously reported cases, the recognition of SLE was delayed because of similar clinical features, regardless of involved organs [8-10]. The liver involvement is often misdiagnosed because jaundice is ascribed to hemolysis and not cholestasis.

An autoantibody production is traditionally a manifestation of autoimmunity. Nearly all our patients had detectable antinuclear antibodies. Whether early autoantibody detection might have helped to diagnose AID is discussed. The prevalence of antinuclear antibodies varies from 12 to $30 \%$ in healthy individuals overall $[21,22]$ and from 7 to $39 \%$ in Africans [23, 24]. Moreover, high autoantibody titers have been reported in SCD in the absence of autoimmunity $[25,26]$. Consequently, routine screening for autoantibodies in the absence of suggestive symptoms is not recommended, because it may be confusing and lead to inadequate diagnosis and therapy. The mechanisms underlying the production of autoantibodies in SCD are unknown but may involve impaired spleen function. Significant autoantibody titers have been found after splenectomy, in the absence of AID [27]. Other hypotheses include immune system overstimulation by multiple transfusions [28] and chronic inflammation [29]. This has not been confirmed in clinical studies [25,26].

The treatment of coexisting AID and SCD is difficult [30]. Our patients experienced recurrent vaso-occlusive crises while on steroids $[7,10,13,30]$. Concomitant red blood cell transfusion or exchange transfusion program may help prevent vaso-occlusive crises but increase the risk of anti-erythrocyte alloimmunization. Half of our patients received hydroxyurea in the first line or after chronic blood 


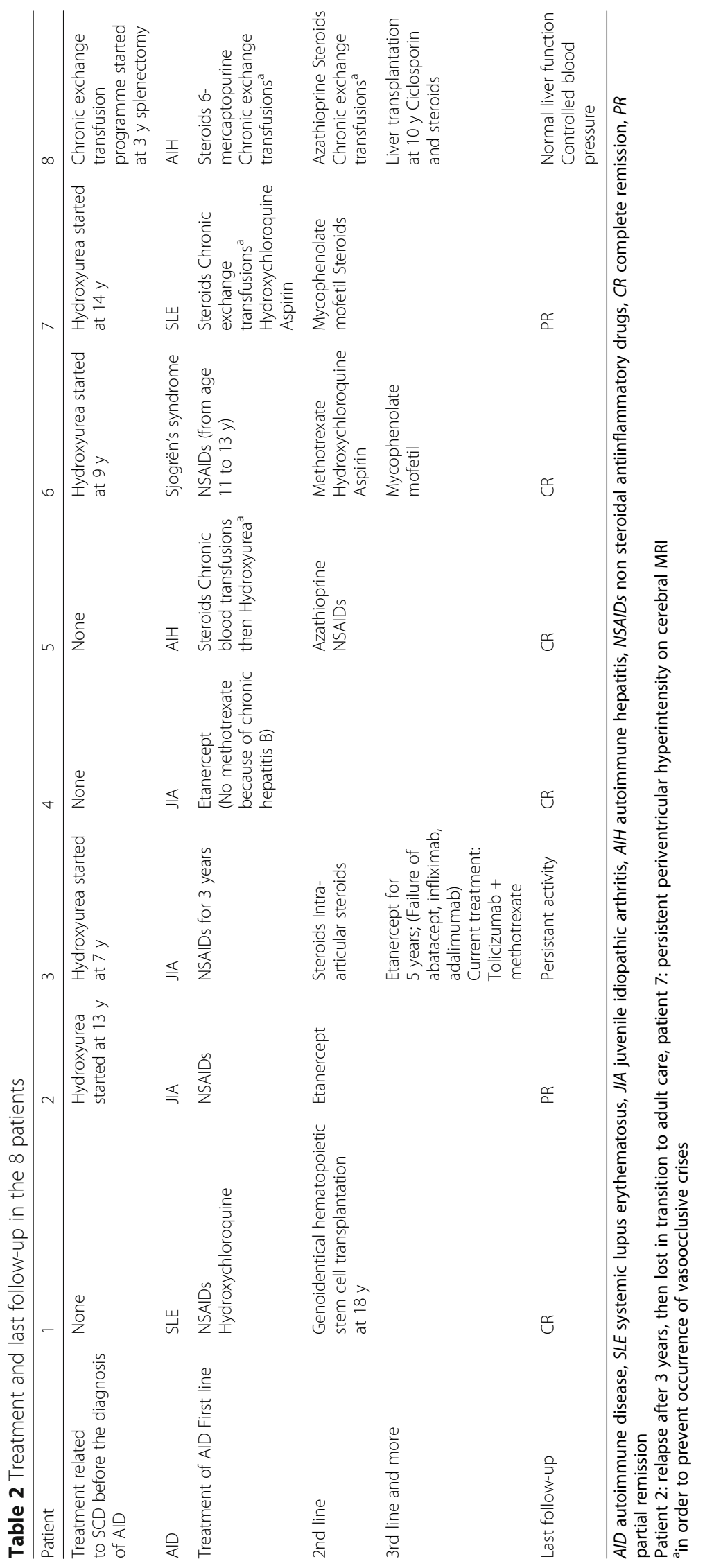


transfusion and experienced fewer vaso- occlusive crises. Hydroxyurea seems to be well tolerated by patients taking antiinflammatory drugs [8-10]. TNF $\alpha$ antagonist therapy (etanercept) was promptly effective in our patients with JIA, as reported in patients with polyarticular onsets of JIA and no SCD [31, 32]. No severe etanercept-related complications were recorded. The few available data suggest good effectiveness and tolerance in patients with SCD $[5,20]$. The use of others biological therapies as anti-interleukine 1 and 6 has not been reported yet in patients with SCD. Azathioprine was frequently used either for patients with SLE or autoimmune hepatitis and was well tolerated [10, 12-14]. For hydroxychloroquine, ocular toxicity may worsen retinopathy due to SCD and has to be regularly controlled. Finally, immunosuppressive and antiinflammatory drugs can induce renal and hepatic toxicity that may be worsened by SCD-related complications. They may further increase the risk of infection [20], despite the lack of published data concerning infections in patients with both AID and SCD. The initiation of immunosuppressive and/or antiinflammatory therapy should be discussed in reference centers and require close monitoring. Biological treatments, including anti-TNF targeted treatments, might be beneficial to SCD-associated AID / inflammation and in some cases to SCD itself and deserve further evaluation [33]. Hematopoietic stem cell transplantation seems to be a good therapeutic option. Liver transplantation can be discussed in very selected cases.

\section{Conclusion}

SCD and AID share many clinical and biological features, and diagnosing AID in patients with SCD can be challenging. Diagnostic delay increases the morbidity and mortality related to both the AID and SCD. Whilst the use of steroids to treat AIDs induced potential severe SCDrelated complications, which justified associated chronic red blood cell transfusions, other treatments such as antiTNF agents were well tolerated. Further studies are needed to determine the prevalence of AID in patients with SCD, to look for pathophysiological links, to earlier diagnose AID, and to define the best therapeutic options.

\section{Abbreviations}

ACS: Acute chest syndrome; AID: Autoimmune disease; AlH: Autoimmune hepatitis; CNIL: Commission Nationale Informatique et Libertés; JIA: Juvenile idiopathic arthritis; SCD: sickle cell disease; SLE: Systemic lupus erythematosus; VOC: Vaso-occlusive crises

\section{Acknowledgements}

Not applicable.

\section{Funding}

The authors declare that they have no funding.

\section{Authors' contributions}

$\mathrm{VL}$ and FU collected data and wrote the manuscript; MM, VB, FL, BB and PQ were involved in the clinical care of the patients and provided data for the study. MM, FL and PQ helped with data management, edited and reviewed the manuscript. All authors read and approved the manuscript.

\section{Ethics approval and consent to participate}

According to the French legislation, no ethics committee agreement was required for such a retrospective survey. Patients data were included in the CEMARA registry for rare diseases which is approved by the French "Commission Nationale Informatique et Liberté" (Landais P, et al. CEMARA an information system for rare diseases. Stud Health Technol Inform 2010;160:481-5).

\section{Consent for publication}

Consent to publish was obtained from the parents or legal guardian, when they agreed to be registered in the CEMARA database.

\section{Competing interests}

The authors declare that they have no competing interests.

\section{Publisher's Note}

Springer Nature remains neutral with regard to jurisdictional claims in published maps and institutional affiliations.

\section{Author details}

'Onco-Hématologie Pédiatrique, Centre Hospitalier Universitaire Amiens, Amiens, France. ${ }^{2}$ Unité d'Immunologie-Hématologie et Rhumatologie Pédiatrique, Centre de référence pour la Rhumatologie et les maladies Auto-immunes Systémiques de l'Enfant, Hôpital Necker-Enfants Malades, Assistance Publique Hôpitaux de Paris, Paris, France. ${ }^{3}$ Université Paris-Descartes, Paris, France. ${ }^{4}$ IMAGINE Institute, Paris, France. ${ }^{5}$ Hépatologie-Gastroentérologie-Nutrition Pédiatrique, Hôpital Necker-Enfants Malades, Assistance Publique Hôpitaux de Paris, Paris, France. ${ }^{6}$ Pédiatrie Générale, Centre de Référence des Hémoglobinopathies, Hôpital Necker-Enfants Malades, Assistance Publique Hôpitaux de Paris Labex-GR-Ex, Paris, France.

Received: 24 June 2017 Accepted: 26 December 2017

Published online: 17 January 2018

\section{References}

1. Johnston RB Jr, Newman SL, Struth AG. An abnormality of the alternate pathway of complement activation in sickle-cell disease. N Engl J Med. 1973;288:803-8.

2. Wilson WA, Nicholson GD, Hughes GR, Amin S, Alleyne G, Serjeant GR. Systemic lupus erythematosus and sickle-cell anaemia. Br Med J. 1976;1:813.

3. Koethe SM, Casper JT, Rodey GE. Alternative complement pathway activity in sera from patients with sickle cell disease. Clin Exp Immunol. 1976;23:56-60.

4. Wilson WA, De Ceulaer K, Morgan AG. Sickle cell anemia, complement, and systemic lupus erythematosus. Arthritis Rheum. 1979;22:803.

5. Adelowo O, Edunjobi AS. Juvenile idiopathic arthritis coexisting with sickle cell disease: two case reports. BMJ. 2011; doi: https://doi.org/10.1136/bcr. 2011.4889.

6. Eberhard BA. Coexistent sickle cell disease and juvenile rheumatoid arthritis: 2 cases with delayed diagnosis and severe destructive arthropathy. J Rheumatol. 2002;29:1802. author reply 1802-3

7. Nistala K, Murray KJ. Co-existent sickle cell disease and juvenile rheumatoid arthritis. Two cases with delayed diagnosis and severe destructive arthropathy. J Rheumatol. 2001;28:2125-8.

8. Appenzeller S, Fattori A, Saad ST, Costallat LT. Systemic lupus erythematosus in patients with sickle cell disease. Clin Rheumatol. 2008;27:359-64.

9. Khalidi NA, Ajmani H, Varga J. Coexisting systemic lupus erythematosus and sickle cell disease: a diagnostic and therapeutic challenge. J Clin Rheumatol. 2005;11:86-92.

10. Saxena VR, Mina R, Moallem HJ, Rao SP, Miller ST. Systemic lupus erythematosus in children with sickle cell disease. J Pediatr Hematol Oncol. 2003;25:668-71.

11. Maamar M, Tazi-Mezalek Z, Harmouche H, Mounfaloti W, Adnaoui M, Aouni M. Systemic lupus erythematosus associated with sickle-cell disease: a case report and literature review. J Med Case Rep. 2012;6:366. 
12. Chuang E, Ruchelli E, Mulberg AE. Autoimmune liver disease and sickle cell anemia in children: a report of three cases. J Pediatr Hematol Oncol. 1997;19:159-62.

13. Lykavieris P, Benichou JJ, Benkerrou M, Feriot JP, Bernard O, Debray D. Autoimmune liver disease in three children with sickle cell disease. J Pediatr Gastroenterol Nutr. 2006:42:104-8.

14. El Younis CM, Min AD, Fiel MI, Klion FM, Thung SN, Faire B, Miller CM, Bodenheimer HC Jr. Autoimmune hepatitis in a patient with sickle cell disease. Am J Gastroenterol. 1996;91:1016-8.

15. Landais P, Messiaen C, Rath A, Le Mignot L, Dufour E, Ben Said M, Jais JP, Toubiana L, Baujat G, Bourdon-Lanoy E, Gérard-Blanluet M, Bodemer C, Salomon R, Aymé S, Le Merrer M, Verloes A, CEMARA task force. CEMARA an information system for rare diseases. Stud Health Technol Inform. 2010;160:481-5.

16. Hopkinson ND, Doherty M, Powell RJ. Clinical features and race-specific incidence/prevalence rates of systemic lupus erythematosus in a geographically complete cohort of patients. Ann Rheum Dis. 1994;53:675-80.

17. Saurenmann RK, Rose JB, Tyrrell P, Feldman BM, Laxer RM, Schneider R, Silverman ED. Epidemiology of juvenile idiopathic arthritis in a multiethnic cohort: ethnicity as a risk factor. Arthritis Rheum. 2007;56:1974-84.

18. Haffejee IE, Raga J, Coovadia HM. Juvenile chronic arthritis in black and Indian south African children. S Afr Med J. 1984;65:510-4

19. Vaiopoulos G, Konstantopolous K, Osterland CK. Asplenia in systemic lupus erythematosus: a simple coincidence? Clin Exp Rheumatol. 1995;13:513-5.

20. Michel M, Habibi A, Godeau B, Bachir D, Lahary A, Galacteros F, FifiMah A, Arfi S. Characteristics and outcome of connective tissue diseases in patients with sickle-cell disease: report of 30 cases. Semin Arthritis Rheum. 2008;38:228-40.

21. de Vlam K, De Keyser F, Verbruggen G, Vandenbossche M, Vanneuville B, D'Haese D, Veys EM. Detection and identification of antinuclear autoantibodies in the serum of normal blood donors. Clin Exp Rheumatol. 1993:11:393-7.

22. Hilário MO, Len CA, Roja SC, Terreri MT, Almeida G, Andrade LE. Frequency of antinuclear antibodies in healthy children and adolescents. Clin Pediatr. 2004;43:637-42.

23. Adebajo AO, Charles P, Maini RN, Hazleman BL. Autoantibodies in malaria, tuberculosis and hepatitis B in a west African population. Clin Exp Immunol. 1993:92:73-6.

24. Greenwood BM, Herrick EM, Holborow EJ. Speckled antinuclear factor in African sera. Clin Exp Immunol. 1970;7:75-83.

25. Baethge BA, Bordelon TR, Mills GM, Bowen LM, Wolf RE, Bairnsfather L. Antinuclear antibodies in sickle cell disease. Acta Haematol. 1990;84:186-9.

26. Toly-Ndour C, Rouquette AM, Obadia S, M'bappe P, Lionnet F, Hagege I, Boussa-Khettab F, Tshilolo L, Girot R. High titers of autoantibodies in patients with sickle cell disease. J Rheumatol. 2011;38:302-9.

27. Balsalobre B, Hernández-Godoy J, Planelles D. Autoantibodies in splenectomized patients as a consequence of abdominal trauma. J Investig Allergol Clin Immunol. 1992;2:91-5.

28. Aygun B, Padmanabhan S, Paley C, Chandrasekaran V. Clinical significance of RBC alloantibodies and autoantibodies in sickle cell patients who received transfusions. Transfusion. 2002:42:37-43.

29. Allen RC, Dewez P, Stuart L, Gatenby PA, Sturgess A. Antinuclear antibodies using HEp-2 cells in normal children and in children with common infections. J Paediatr Child Health. 1991;27:39-42.

30. Couillard S, Benkerrou M, Girot R, Brousse V, Ferster A, Bader-Meunier B. Steroid treatment in children with sickle-cell disease. Haematologica. 2007:92:425-6.

31. Quartier P, Taupin P, Bourdeaut F, Lemelle I, Pillet P, Bost M, Sibilia J, Koné-Paut I, Gandon-Laloum S, LeBideau M, Bader-Meunier B, Mouy R, Debré $M$, Landais P, Prieur AM. Efficacy of etanercept for the treatment of juvenile idiopathic arthritis according to the onset type. Arthritis Rheum. 2003:48:1093-101.

32. Horneff $G$, Schmeling H, Biedermann T, Foeldvari I, Ganser G, Girschick HJ, Hospach T, Huppertz HI, Keitzer R, Küster RM, Michels H, Moebius D, Rogalski B, Thon A, Paediatric Rheumatology Collaborative Group. The German etanercept registry for treatment of juvenile idiopathic arthritis. Ann Rheum Dis. 2004;63:1638-44.

33. Solovey A, Somani A, Chen $C_{\text {, }}$ et al. Interference with TNFa using long-term etanercept in $\mathrm{S}^{+} S^{\text {Antilles }}$ sickle transgenic mice ameliorates abnormal endothelial activation, vasoocclusion, and pulmonary hypertension including its pulmonary arterial wall remodeling. Blood. 2013;122:728.

\section{Submit your next manuscript to BioMed Central and we will help you at every step:}

- We accept pre-submission inquiries

- Our selector tool helps you to find the most relevant journal

- We provide round the clock customer support

- Convenient online submission

- Thorough peer review

- Inclusion in PubMed and all major indexing services

- Maximum visibility for your research

Submit your manuscript at www.biomedcentral.com/submit 